\section{Epidural sufentanil for post-Caesarean section analgesia: lack of benefit of epinephrine}

G. H. McMorland MB ChB DA FRCPC, M.J. Douglas MD FRCPC, J.H.K. Kim, MD FRCPC, A.A. Kamani MD FRCPC, J.E. Swenerton, MD FRCPC, J. Berkowitz PhD, P.L.E. Ross MD BSc(Meds), FRCPC, L. Palmer, RN
Epidural sufentanil was administered to 57 women after Caesarean section, under epidural anaesthesia, to provide postoperative analgesia. Each patient received a $30 \mu \mathrm{g}$ dose at the first complaint of pain and this dose was repeated when pain recurred. Epinephrine $(1: 200,000)$ was added to the local anaesthesic, sufentanil, both, or neither. The time of onset of analgesia, efficacy, duration of analgesia and the incidence of side-effects were recorded. This dose of epidural sufentanil provided satisfactory postoperative analgesia and no serious side-effects were observed. The onset of analgesia was rapid (4-6 min), but the duration of action was brief (4-5 hr). The addition of 1:200,000 epinephrine had no statistically significant influence on any of the measured variables. Pruritus occurred commonly but never required treatment. Drowsiness was experienced frequently and was felt by some patients to inhibit their interaction with their neonates. Respiratory depression, as defined by a respiratory rate less than $10 \mathrm{bpm}$, was not observed. A number of patients noted a transient period of euphoria 5-8 min after administration of the epidural sufentanil. The authors feel that epidural sufentanil provides satisfactory analgesia after Caesarean section, but the brief duration of action and the high incidence of drowsiness limit its acceptability for routine use in obstetric patients.

Le sufentanil en injection épidurale fut administré à 57 femmes après césarienne pour l'analgésie postopératoire. Chaque patiente a reçu $30 \mu \mathrm{g}$ lors de la première douleur et celle dose

\section{Key words}

ANAESTHESIA: obstetric;

ANALGESICS: sufentanil;

ANAESTHETIC TECHNIQUES: epidural.

From the Department of Anaesthesia, University of British Columbia and Grace Hospital, Vancouver, B.C., Canada.

Address correspondence 10: Dr. G.H. McMorland, Department of Anaesthesia, Grace Hospital, 4490 Oak Street, Vancouver, B.C. V6H 3 V5.

This study was supported by a grant from Janssen Pharmaceutica. fut répétée quand la douleur est revenue. L'épinéphrine. (1:200,000) fut ajouté à l'anesthésie locale, le sufentanil, au deux, ou à aucun. Le temps d'installation d'analgésie, l'efficacité, la durée de l'analgésie et l'insuffisance des effets secondaires furent enregistrés. Cette dose de sufentanil en injection épidurale a fourni une analgésie postopératoire satisfnisante et aucun effet secondaire fut observé. Le début de l'analgésie fut rapide (4-6 min), mais la durée d'action fut brève (4-5 hre). L'addition de l:200,000 épinéphrine n'a eu aucune influence statistiquement significative sur aucune des mesures éludiées. Le prurit fut le plus communément observé mais n'a jamais requis un traitement. La somnolence fut observée fréquemment et certaines patientes l'attachait en la diminution de leur interaction avec les nouveau-nés. La dépression respiratoire définie par une fréquence respiratoire inférieure à 10 resp/min ne fut pas observée. Un certain nombre de patientes on noté une période transitoire d'euphorie de cinq à huit minutes après l'administration de sufentanil en injection épidurale. Les auteurs pensent que le sufentanil en injection épidurale fournit une analgésie satisfaisante après une césarienne mais une durée d'action courte et la haute incidence de somnolence limitent son acceptabilité de routine pour les patientes en obstétrique.

Sufentanil, a thienyl analogue of fentanyl, is a highly lipid-soluble narcotic agonist and is characterised by a significantly higher affinity for $\mu$-opiate receptor sites than fentanyl.' It has been reported to be five to seven times more potent than fentanyl. ${ }^{2}$ Previous studies ${ }^{3-7}$ have shown that epidurally administered sufentanil provided rapid and dose-related pain relief in postoperative patients. However, the duration of action was short and Cohen $^{5}$ and Parke $^{8}$ reported that addition of epinephrine to epidural sufentanil did not prolong the duration of analgesia. However, epinephrine was routinely added to the epidural local anaesthetic used during the Caesarean section and it is possible that this had some residual effect in their patients.

This study was designed to evaluate the analgesic potency and duration of action of epidural sufentanil, administered after Caesarean section, and to examine the effect of addition of epinephrine on these variables. 


\section{Methods}

The study was approved by the Clinical Screening Committee for Research Involving Human Subjects, University of British Columbia, and written informed consent was obtained from all patients.

Fifty-seven healthy term parturients, who were scheduled for elective Caesarean section under epidural anaesthesia, were enrolled in the study and were assigned to one of four groups, using a randomisation table. Three of the original 60 patients were dropped from the study because of postoperative problems, unrelated to the sufentanil analgesia.

\section{Group I}

Received an epidural anaesthetic with plain carbonated lidocaine ( 1.73 per cent) or 0.5 per cent bupivacaine, followed postoperatively by $30 \mu \mathrm{g}$ epidural sufentanil in $10 \mathrm{ml}$ normal saline on complaint of pain $(n=14)$.

\section{Group 2}

Received an epidural anaesthetic with carbonated lidocaine or 0.5 per cent bupivacaine, with $1: 200,000$ epinephrine freshly added, followed by $30 \mu \mathrm{g}$ epidural sufentanil in $10 \mathrm{ml}$ normal saline at onset of pain $(n=13)$.

\section{Group 3}

Received an epidural anaesthetic with plain carbonated lidocaine or 0.5 per cent bupivacaine, followed postoperatively by $30 \mu \mathrm{g}$ epidural sufentanil with $1: 200,000$ epinephrine added $(n=15)$.

\section{Group 4}

Received an epidural anaesthetic with carbonated lidocaine or 0.5 per cent bupivacaine, with freshly added $1: 200,000$ epinephrine, followed postoperatively by $30 \mu \mathrm{g}$ epidural sufentanil with 1:200,000 epinephrine $(n=15)$.

The anaesthetist, research nurse and patient were all blinded to the presence or absence of epinephrine in either local anaesthetic or sufentanil solutions.

An epidural catheter was inserted at $L_{2 / 3}$ or $L_{3 / 4}$ interspace and advanced cephalad for $3 \mathrm{~cm}$. Following an initial $3 \mathrm{ml}$ "test dose," the remainder of the local anaesthetic was injected in $3-5 \mathrm{ml}$ incremental doses to establish a sensory block to about the fourth thoracic dermatome. At the completion of surgery the patients were transported to the post-anaesthetic recovery room. At the time of an initial complaint of pain, sufentanil was administered via the epidural catheter, which was left in situ. When pain recurred a second dose of sufentanil was administered and the epidural catheter removed. The first and second doses were identical with respect to the presence or absence of epinephrine.

The following variables were assessed five minutes before and at 5, 10,20 and 30 min and then hourly until nine hours after the injection of the epidural opioid:

A Pain-recorded on a $100 \mathrm{~mm}$ linear analogue scale and the site of the pain noted.

B Pruritus - recorded on a $100 \mathrm{~mm}$ linear analogue scale and the site of the itch noled.

C Nausea - graded as: none, present only with movement, or present when at rest.

D Vomiting - graded as: none, single episode, multiple episodes.

E Somnolence - graded as: awake, responsive, unresponsive.

F Urinary retention - the need to recatheterise

G Respiratory rate - if the rate fell below ten bpm, end-tidal $\mathrm{CO}_{2}$ and arterial blood gases were measured.

Each patient was monitored throughout the study period by the research nurse.

\section{Statistical analysis}

Summary statistics were computed for each of the covariates of age, height, weight and parity, for each of the four experimental groups. The primary response variable, namely, the time to medication after the second dose of sufentanil, was studied using a two-way analysis of variance with interaction. This was possible because the four groups were arranged in a $2 \times 2$ factorial design, where the first factor was sufentanil, with or without epinephrine, and the second factor was the epidural anaesthetic, with or without epinephrine. The two-way layout allowed for simultaneous tests of the main effects of the two factors and interaction effects.

The effects of epinephrine on the analgesic potency and duration of sufentanil and the epidural anaesthetic were also examined separately by pooling the groups. That is, a comparison of sufentanil without and with epinephrine was made by combining Group 1 with Group 2 and Group 3 with Group 4 . Similarly, the effect of epinephrine on the epidural anaesthetic was studied by combining Group I with Group 3 and Group 2 with Group 4. Two sample 1 tests were used to compare the pooled groups using onset time and duration of each dose as response variables.

Pain scores (as recorded on a $100 \mathrm{~mm}$ visual analogue scale) were studied first by plotting mean scores over time, by group. Frequency tables were compiled using three categories of pain: mild $(0-30)$, moderate $(31-70)$, and severe $(71-100)$ and ten time points, from control (baseline) to six hours. The tables were reduced in size by combining the moderate and severe pain categories and by considering only four time points: Control, $5 \mathrm{~min}, 15 \mathrm{~min}$, and $1 \mathrm{hr}$. The differences among the four groups over time were assessed using chi-squared tests of independence (Tables IV and V). 
TABLE I Demographic data

\begin{tabular}{lllll}
\hline & Group 1 & Group 2 & Group 3 & Group 4 \\
\hline Age (yr) & $31.2 \pm 3.9$ & $33.4 \pm 4.6$ & $32.3 \pm 3.3$ & $30.8 \pm 5.0$ \\
Height $(\mathrm{cm})^{*}$ & $157.6 \pm 6.2$ & $159.5 \pm 6.3$ & $160.1 \pm 7.4$ & $159.0 \pm 7.9$ \\
Weight (kg)* & $78.2 \pm 16.5$ & $75.5 \pm 11.2$ & $72.5 \pm 10.7$ & $79.2 \pm 16.6$ \\
Sample size & 14 & 13 & 15 & 15 \\
Parily (N/M) & $2 / 12$ & $3 / 10$ & $1 / 14$ & $2 / 13$ \\
\hline
\end{tabular}

*Values expressed as mean $\pm \mathrm{SD}$.

TABLE II Onset time and duration

\begin{tabular}{lllll}
\hline & Group I & Group 2 & Group 3 & Group 4 \\
\hline Onset time (min)* & & & & \\
- dose 1 & $4.8 \pm 2.1$ & $5.5 \pm 1.8$ & $6.2 \pm 2.9$ & $6.2 \pm 3.3$ \\
- dose 2 & $4.6 \pm 2.0$ & $5.1 \pm 3.8$ & $4.6 \pm 0.8$ & $5.3 \pm 1.9$ \\
Duration (min)* & & & & \\
- dose 1 & $290.6 \pm 50.3$ & $261.2 \pm 60.8$ & $304.1 \pm 98.9$ & $291.3 \pm 50.0$ \\
- dose 2 & $230.4 \pm 66.9$ & $219.2 \pm 67.7$ & $260.4 \pm 144.0$ & $231.3 \pm 69.3$ \\
\hline
\end{tabular}

*Values expressed as mean $\pm \mathrm{SD}$.

Pruritus was analysed using two-sample $\mathrm{t}$ tests to compare the pooled groups as discussed above.

\section{Results}

The four groups were similar with respect to age, height, weight and parity (Table I). Onset times and duration of analgesia were also comparable among the four groups, for both doses of sufentanil (Tables II and III). In all groups the duration of analgesia was shorter, on average, after the second dose of sufentanil, but because of the wide variability this was not statistically significant.

\section{Pain scores}

There were no statistically significant differences in pain scores among the four groups at any of the recorded times after each dose of sufentanil (Table IV). When groups were paired to consider the effect of addition of epineph-

TABLE III Effect of epinephrine on onset and duration of sufentanil

\begin{tabular}{|c|c|c|c|}
\hline & \multicolumn{3}{|l|}{ Sufentanil } \\
\hline & $\begin{array}{l}\text { with } \\
\text { epinephrine } \\
\text { (Groups / \& 2) }\end{array}$ & $\begin{array}{l}\text { without } \\
\text { epinephrine } \\
\text { (Groups } 3 \& 4 \text { ) }\end{array}$ & $P$ value \\
\hline \multicolumn{4}{|c|}{ Onset time (min)* } \\
\hline - dose I & $5.15 \pm 1.94$ & $6.20 \pm 3.08$ & 0.1 \\
\hline - dose 2 & $4.85 \pm 3.01$ & $5.00 \pm 1.5$ & 0.8 \\
\hline \multicolumn{4}{|c|}{ Duration (min)* } \\
\hline - dose I & $276.4 \pm 55.6$ & $297.7 \pm 78.4$ & 0.2 \\
\hline - dose 2 & $225.0 \pm 67.3$ & $244.8 \pm 110.3$ & 0.4 \\
\hline
\end{tabular}

*Time recorded as mean $\pm S D$. rine to either the local anaesthetic or to sufentanil (i.e., Groups 1 and 3 compared with Groups 2 and 4; and Groups 1 and 2 compared with Groups 3 and 4 ) there were, again, no significant differences noted suggesting that epinephrine had no significant influence on the intensity of postoperative analgesia produced by epidural sufentanil.

\section{Side-effects}

1 Pruritus - The incidence (Table $V$ ) of pruritus, the onset time, duration and maximum intensity recorded (Table VI), were all similar for both sufentanil doses. While the incidence appeared to be slightly lower after the second dose of sufentanil, this was not statistically significant. None of the patients experienced pruritus severe enough to require treatment.

2 Nausea and vomiting - The overall incidence was low and was similar among the four groups. Only four patients required treatment for vomiting, all of them after the second dose of epidural sufentanil.

3 Somnolence - Drowsiness was frequently recorded in all groups and a few patients complained that it inhibited their interaction with their neonates.

4 Euphoria - was experienced in nine patients in Group I, three each in Groups 2 and 3 and five patients in Group 4. The onset was between five and eight minutes after administration of sufentanil and the duration was brief (14 to 20 minutes).

5 Urinary retention - This proved to be impossible to evaluate because of the usual practice of leaving indwelling bladder catheters for varying lengths of time, following Caesarean section. 
TABLE IV Pain scores ( $\mathrm{mm}$ on VAS)

\begin{tabular}{rlccc}
\hline & Conirol & $5 \min$ & $15 \min$ & $60 \min$ \\
\hline Dose I & & & & \\
Group 1 & $49.8(21-80)$ & $25.2(0-75)$ & $5.4(0-35)$ & $0(0)$ \\
2 & $45.2(8-83)$ & $32.3(0-89)$ & $5.2(0-34)$ & $0.9(0-7)$ \\
3 & $48.7(11-81)$ & $34.3(0-81)$ & $14.3(0-61)$ & $6.1(0-28)$ \\
4 & $49.1(14-82)$ & $30.7(0-73)$ & $11.8(0-52)$ & $2.7(0-41)$ \\
& & & & \\
Dose 2 & & & & \\
Group 1 & $48.6(5-87)$ & $29.5(0-67)$ & $11.1(0-59)$ & $4.3(0-45)$ \\
2 & $48.9(4-93)$ & $28.8(2-94)$ & $11.7(0-43)$ & $5.2(0-48)$ \\
3 & $62.3(8-96)$ & $45.9(3-87)$ & $26.2(0-96)$ & $15.7(0-95)$ \\
4 & $49.7(11-82)$ & $28.6(6-69)$ & $12.5(1-45)$ & $5.0(0-43$ \\
\hline
\end{tabular}

Mean (range).

TABLE V Incidence of prurilus

\begin{tabular}{lrlrll}
\hline & \multicolumn{2}{l}{ First dose } & & \multicolumn{2}{c}{ Second dose } \\
\cline { 2 - 3 } \cline { 5 - 6 } Group & \multicolumn{1}{l}{$n$} & $\%$ & & \multicolumn{1}{c}{$n$} & $\%$ \\
\hline $1(n=14)$ & 11 & 78.6 & 9 & 64.3 \\
$2(n=13)$ & 11 & 84.6 & & 10 & 76.9 \\
$3(n=15)$ & 9 & 60 & & 8 & 53.3 \\
$4(n=15)$ & 11 & 73.3 & & 7 & 46.7 \\
\hline
\end{tabular}

6 Respiratory depression - No patients in this study had respiratory rates below ten breaths per minute and, thus, no end-tidal $\mathrm{CO}_{2}$ nor arterial blood gas measurements were done.

\section{Discussion}

Epidural opioids, for relief of postoperative pain, have become widely used and accepted. ${ }^{9}$ The most commonly used narcotic, for this purpose, is morphine, which produces excellent analgesia of long duration. However, it is also associated with a high incidence of side-effects, such as pruritus, urinary retention, delayed respiratory depression, nausea and vomiting. ${ }^{10.11}$ These side-effects may be uncomfortable or, in the case of respiratory depression, life-threatening.

Sufentanil, because of its potency and lipid solubility, ${ }^{1,2}$ has been investigated as an epidural analgesic in postoperative patients. ${ }^{3-7}$ While parturients do not manifest the same incidence of respiratory depression, ${ }^{10-12}$ after epidural morphine, as older patients with systemic (especially respiratory) disease, they do exhibit a disturbingly high incidence of other side-effects, especially pruritus.

Epidural fentanyl has been shown to provide good analgesia after Caesarean section ${ }^{13}$ with a low risk of delayed respiratory depression. ${ }^{14}$ The disadvantage is the short duration of action. The addition of epinephrine to epidural fentanyl was studied and found to have no significant effect on the duration of analgesia, but markedly increased the incidence of pruritus. ${ }^{15}$ Madej and Strunin ${ }^{16}$ compared epidural administration of fentanyl with sufentanil. They reported a statistically, but not clinically, significant reduction in respiratory rate in the fentanyl group. Sufentanil $50 \mu \mathrm{g}$ had an unacceptably high incidence of side-effects.

The present study was designed to examine the analge-

TABLE VI Onsel direction and intensity of pruritus

\begin{tabular}{lcccc}
\hline & Group I & Group 2 & Group 3 & Group 4 \\
\hline $\begin{array}{llll}\text { Onset time (min)* } \\
- \text { dose 1 }\end{array}$ & $42.7 \pm 30.9$ & $47.7 \pm 37.2$ & $58.3 \pm 38.6$ & $55.9 \pm 25.2$ \\
- dose 2 & $27.1 \pm 17.3$ & $66.7 \pm 72.8$ & $64.3 \pm 43.1$ & $68.6 \pm 77.4$ \\
$\begin{array}{l}\text { Duration (min)* } \\
\text { - dose 1 }\end{array}$ & $160.5 \pm 70.6$ & $135.0 \pm 62.6$ & $150.0 \pm 91.2$ & $139.1 \pm 102.4$ \\
- dose 2 & $107.7 \pm 91.8$ & $118.5 \pm 93.9$ & $148.1 \pm 104.7$ & $111.4 \pm 115.8$ \\
$\begin{array}{l}\text { Maximum intensity* } \\
\quad \text { (mm on VAS) }\end{array}$ & & & & \\
- dose 1 & $36.9 \pm 20.1$ & $27.6 \pm 26.8$ & $28.1 \pm 25.0$ & $16.2 \pm 14.5$ \\
- dose 2 & $18.1 \pm 17.9$ & $10.0 \pm 12.8$ & $26.8 \pm 24.9$ & $13.4 \pm 20.8$ \\
\hline
\end{tabular}

*Values recorded as mean $\pm \mathrm{SD}$. 
sic potency of $30 \mu \mathrm{g}$ epidural sufentanil and to determine whether the addition of epinephrine would increase the potency and duration of analgesia and modify the incidence and severity of side-effects. In each of the four groups studied, this dose of sufentanil provided rapid and effective analgesia. The addition of epinephrine to either the local anaesthetic, or sufentanil, or both, had no significant influence on these variables, nor on the duration of action. However, Naulty ${ }^{6}$ did observe a prolongation of analgesia when epinephrine was added to 25 and $50 \mu \mathrm{g}$ doses of epidural sufentanil.

There were no serious side-effects noted in this study. No patients had respiratory rate less than ten breaths per minute. However, Labaille et al. ${ }^{17}$ reported a significant reduction in the slope of the $\mathrm{CO}_{2}$ response curve after epidural sufentanil in both 50 and $30 \mu \mathrm{g}$ doses. In the case of the $30-\mu \mathrm{g}$ dose, this occurred at 45 and 120 min after administration of the drug, while it occurred earlier (15 $\mathrm{min}$ ) after a $50-\mu \mathrm{g}$ dose.

Drowsiness was a common side-effect in this study and this was also noted by Donadoni ${ }^{3}$ and Cohen. ${ }^{5}$ While this may be advantageous in most postoperative patients, our post-Caesarean section patients frequently complained that it inhibited interaction with their neonates. A transient period of euphoria was noted in a number of patients, shortly after administration of the drug. Cohen ${ }^{5}$ reported peak serum sufentanil levels ten minutes after either intravenous or epidural administration of sufentanil. The early onset and brief duration of euphoria may be related to this systemic absorption of the drug. Pruritus occurred commonly, but in no case was it sufficiently severe as to require treatment. In contrast to our earlier experience with epidural fentanyl, ${ }^{15}$ the addition of epinephrine did not affect the incidence, nor the severity, of the pruritus.

The wide variability in scores (particularly with respect to duration), combined with the snall sample size, resulted in low power to detect significant differences. For example, the best estimate of the effect of adding epinephrine to sufentanil was that the duration (as measured by time to supplemental analgesic medication after the second dose) was increased by about $20 \mathrm{~min}$. However, this was not statistically significantly different from zero. Group 3, in particular, had an extremely large range of recorded durations. Overall, there was no evidence of a statistically significant influence of epinephrine on the intensity of analgesia. Neither is there any statistical evidence of any difference among the four groups on measures of pruritus, onset time, duration or maximum intensity.

In summary, this study has demonstrated that epidural administration of $30 \mu \mathrm{g}$ of sufentanil will provide satisfactory analgesia after Caesarean section with a rapid onset, but brief duration of action. At this dose we observed no serious side-effects but the high incidence of drowsiness may be a disadvantage in obstetric patients.

\section{Acknowledgements}

The authors wish to acknowledge the assistance of Ms. Lois Obenauer in the preparation of this manuscript and Patricia Thompson R.N., in preparation of the protocol for the study.

\section{References}

1 Leysen JE, Commeren W, Niemegeers CJE. $\left[{ }^{3} \mathrm{H}\right]$ Sufentanil, a superior ligand for $\boldsymbol{\mu}$-opiate receptors: binding properties and regional distribution in rat brain and spinal cord. Eur J Pharmacol 1983; 87 : 209-25.

2 Niemegeers CJE, Schellekens KHL, Van Berer WFM, Janssen PAJ. Sufentanil, a very potent and extremely safe intravenous morphine-like compound in mice, rats and dogs. Arzneimittelforschung 1976; 26: 1551-6.

3 Donadoni $R$, Rolly $G$, Noorduin $H$, van den Busche $G$. Epidural sufentanil for postoperative pain relief. Anaesthesia 1985; 40: 634-8.

4 Verborgh C, van der Auwera D, van Droogenbroek E, Camu $F$. Epidural sufentanil for postsurgical pain relief. Eur J Anaesthesiol 1986; 3: 313-20.

5 Cohen $S E$, Tan $S$, White PF. Sufentanil analgesia following cesarean section: epidural versus intravenous administration. Anesthesiology 1988; 68: 129-34.

6 Naulty JS, Sevarino FB, Lema FJ, Humt CO, Dana S, Ostheimer $G W$. Epidural sufentanil for postcesarean delivery pain management. Anesthesiology 1986; 65: A396.

7 Rosen MA, Dailey PA, Hughes SC et al. Epidural sufentanil for postoperative analgesia after cesarean section. Anesthesiology 1988; 68: 448-54.

8 Parker EO, Brookshire GL, Bartell SJ, Menard RG, Culverhouse ED. Effects of epinephrine on epidural fentanyl, sufentanil and hydromorphone for postoperative analgesia. Anesthesiology 1985; 65: A235

9 Cousins MJ, Mather LE. Intrathecal and epidural administration of opioids. Anesthesiology 1984; 61: 276-310.

10 Gustafsson LL, Schildt B, Jacobsen $K$. Adverse effects of extradural and intrathecal opiates: report of a nationwide survey in Sweden. Br J Anaesth 1982; 54: 479-86.

11 Leicht CH, Hughes SC, Dailey PA, Shnider SM, Rosen $M A$. Epidural morphine sulfate for analgesia after Cesarean section: a prospective report of 1000 patients. Anesthesiology 1986; 65: A366.

12 Brownridge $P R$. Epidural and intrathecal opiates for postoperative pain relief. Anaesthesia 1983; 38: 74-5. 
13 Naulty JS, Datta S, Ostheimer GW, Johnson MD, Burger $G A$. Epidural fentanyl for post-cesarean delivery pain management. Anesthesiology 1985; 63: 694-8.

14 Abuja BR, Strunin L. Respiratory effects of epidural fentanyl. Anaesthesia 1985; 40: 949-55.

15 Robertson $K$, Douglas MJ, McMorland GH. Epidural fentanyl, with and without epinephrine for post-

Caesarean section analgesia. Can Anaesth Soc J 1985; 32: 502-5.

16 Madej $T$, Strunin $L$. Comparison of epidural fentanyl with sufentanil. Anaesthesia 1987; 42: 1156-61.

17 Labaille T, Benhamon D, Levron JC, Cohen SE. $\mathrm{CO}_{2}$ sensitivity following epidural sufentanil in Cesarean section patients. Anesthesiology 1988; 69: A702. 